This is an Accepted Manuscript of an article published by Taylor \& Francis in Textual Practice on 17/12/2013, available online: http://www.tandfonline.com/doi/abs/10.1080/0950236X.2013.858068. 


\section{Post-Traumatic Memory Projects: Autobiographical Fiction and}

\section{Counter-monuments}

By Dr Meg Jensen, Centre for Life Narratives, Kingston University

Contact details:

Dr Meg Jensen

Deputy Head of School, Humanities

Director, Centre for Life Narratives

Kingston University

Penrhyn Road, Kingston Upon Thames, Surrey KT1 2EE

m.jensen@kingston.ac.uk

07912177216 


\section{Post-Traumatic Memory Projects: Autobiographical Fiction and}

\section{Counter-monuments}

'Perhaps - I am just asking- perhaps literature, in the company of the 'I' which

has forgotten itself, travels the same path as art, toward that which is mysterious and alien. [...] I know, there are other, shorter paths. But after all, literature, too, often shoots ahead of us.' Paul Celan, The Meridian ${ }^{1}$

In the essay 'Virtual Commemoration: The Iraqi Memorial Project', Joseph DeLappe and David Simpson reflect on the nature of public monuments commemorating historical trauma and what they term 'counter-monumental gestures.' They compare the 'alternative memorialisation' of 'virtual monuments,' such as are continually updated online at iraqimemorial.org, as against traditional, static monuments that 'regurgitate the grandiose gestures of a vengeful patriotism that insists on claiming that death is somehow worthwhile.' Traditional monuments, they argue, require 'money and above all peacetime' and in Iraq 'even living memory is insecure.' When memorials are constructed, DeLappe and Simpson ask 'Who is remembered? Who is mourned? Who is responsible for remembering and mourning, and how can artists respond ${ }^{\prime 2}$ In Leigh Gilmore's work on autobiographical fiction that has its roots in traumatic experience, she uses a similar terminology of public commemoration: an autobiography, she argues 'is a monument to the idea of personhood, to the notion that one could leave behind a memorial to oneself. ${ }^{3}$ What precisely, one might ask, is the difference between lived events that may or may not be 
remembered by us or others, and a textual monument to our 'personhood,' framed as a memorial to oneself? Is one 'truer' than another, or are they simply different sites through which to explore the relations between trauma, knowledge, power and meaning?

These inquiries bring to mind the four questions Michel Foucault presents as central to any examination of truth telling: 'who is able to tell the truth, about what, with what consequences, and with what relation to power? $?^{14}$ Whether we are considering building monuments, conceiving virtual memorials or writing textual responses to the past, these questions remind us of the complexities of and pressures upon both truth and telling everywhere it occurs. Moreover, these pressures are nowhere more troubling, frustrating and contested than where tales of trauma attempt to be told. As Shoshana Felman has noted, contemporary history is 'crystallized around these two poles: the trial (law and justice) on the one hand, and trauma, $[. .$.$] on the other hand. { }^{5}$ In this bi-polar world, the longing for justice through speech increases as does the insecurity of the very category through which such justice might be achieved: memory.

As Andreas Huyssen argues, struggles 'over public memory involving historical trauma, genocide, human rights violations and their aftereffects abound in the world today. Monuments, memorials, public sculptures, commemorative sites, and museums are being created at an accelerated pace the world over.' Nevertheless, he notes, 'public memory [...] cannot be stored forever nor can it be secured by monuments. ${ }^{6}$ Or, in the words of Robert Musil, 'there is nothing as invisible as a monument. ${ }^{7}$ While once we might have believed that monuments memorialized heroes and autobiographies recounted generally 
truthful lives of the great, in our age the categories of memory, monumentality, and truth telling are all far from stable.

In this essay, I will argue that this contingency has not only come to supersaturate concrete and textual representations of traumatic experience, but also, to link the discourses with which these very different kinds of renderings are discussed and debated. As Gilmore puts it, they have the 'potential to reorganize what justice and knowledge look like in the context of trauma. ${ }^{8}$ The seemingly distinct memory projects manifested in, for example, war memorials, autobiographical literature, legal testimony and the speech of victims of posttraumatic stress disorders, have, I suggest, developed against and alongside a common set of problematic conceptual, linguistic and socio/political principles. The result of this process is that each of these projects similarly map out and produce idiosyncratic representations of the nature of these boundaries, the genre-blurring and interdisciplinary character of which my own argument echoes.

\section{Legacies of Self-Representation}

Two strange things happened on the day I first sat down to think about this essay. I received an email from a friend of mine, a well-known writer who is publishing a memoir. In it, she said, is 'a little mention of you, or part of you mixed with a couple of other people, so I just wanted you to run your eye over it.' A few years back, this same friend had published a novel in which I thought I recognized myself. The character was a lecturer, teaching the poems of Hart Crane, and a struggling single mother (all of which I was at the time), flamboyantly dressed, dramatic and heavy-set. I don't recognize myself in these last three characteristics-but who is to say how we appear to others? Well, 
actually, the writer is the one to say. Saying how she sees is how she earns a living. That character, my friend assured me, was an amalgam of me and several other people and things she made up. Nevertheless I was wary about the memoir. But read it I did. And there, in two beautifully crafted paragraphs were distilled the history of my divorce, my struggles, and my recent remarriage. My (new) husband saw me crying at my desk and said 'what's wrong?' I pointed to the screen. He read too. 'Is this true?' I asked him. 'Is this how it was?' 'It is part of the truth' he said. 'It is R's view-her truth about your life.' Of course he was right. 'So why am I crying?' I asked.

A few hours later a police officer was taking a witness statement from me. I have witnessed two robberies recently near my house, and the officer wants to write down everything I saw 'in my own words.' He says this several times 'in your own words' but he is filling in the form long before I have said anything and using language I would never use. 'I had a clear and unobstructed view from my window. The male I will call 'Male $A$ ' proceeded to break down the door with a large mallet while another male, 'Male B' revved the engine of a waiting motorcycle. I was approximately 15 to 20 feet from Male A when he entered the premises, etc.' At the beginning of the interview I am anxious-how can I sign an affirmation that these are 'my words?' Will the case fall apart if I do not? I don't want those criminals coming back. And I don't remember all the details. What the colour of their clothes were, what kind of motorcycle it waswere they tall or short? I tell the policeman this, and tell him how scared I was. That I was once the victim of a violent crime and that I shake at loud noises. The statement he reads back to me at the end of the hour says none of these 
things. Nevertheless, I am comfortable with signing it off as an accurate account of what I saw. I compliment the officer on his eye for detail. 'I guess I have written enough of these things by now,' he says. I approve both versions of my life story, one for my friend's memoir and one for the police officer. As he drives off, I think about the legacy of my testimony, but also the legacy of my life story, as told by friend and in my own works of autobiographical fiction.

In addition to the self who has appeared in the work of others, I also write autobiographical fiction. Much of this work, is, moreover informed by (I could say 'haunted by') a series of traumatic childhood events. This is, as Gilmore's work explores, no coincidence. Many writers of autobiographical works that push at the boundaries of truth and fiction, have suffered trauma in childhood. The works Gilmore examines (Dorothy Allison's Bastard out of Carolina; Mikal Gilmore's Shot in the Heart, the serial autobiographies of Jamaica Kincaid and Jeanette Winterson's Written on the Body) develop alongside an aesthetic of trauma that Gilmore terms the 'limits of autobiography.' This aesthetic troubles borderlines, blurs agency, and like the multiple textual representations of me in which I colluded, offers alternative contexts through which to interrogate the traumatic self.

\section{The Aesthetics of Trauma}

The multiple pressures upon the representation of traumatic experience whether in autobiographical fictions or in commemorative artwork, suggest we may need an alternative aesthetics for interpreting such projects. In answer to this requirement, the historian Saul Friedlander calls for an 'aesthetics that remarks on its own limitations, its inability to provide external answers and stable 
meaning [...] that devotes itself primarily to the dilemmas of representation.' It is this very aesthetic that appears to be at work in much post-traumatic autobiographical fiction. Such texts are precisely the exploration of limitationsas the post-traumatic writer, compelled to testify to the past, is unwilling to write purely imaginative fiction but equally unable to write a memoir that might suggest, the possibility of 'external answers and stable meaning.' The result is a narrative 'primarily' concerned with 'the dilemmas of representation,' often fragmentary and intertextual in character. ${ }^{9}$ Friedlander suggests, moreover, that the reason for such a strategy is that it 'sustains uncertainty'-enabling the writer to continue writing for a lifetime-and also 'allows' the writer to 'live without full understanding.' 10

As recent research into post-traumatic stress suggests, such an aesthetic is particularly suited those who suffer from the disorder (knowingly or otherwise): PTSD, it seems, has a particular effect upon its victims' relationship to language and meaning. Psychoanalyst and critic Juliet Mitchell calls this effect 'the pseudosymbolic language of post-trauma.' As Mitchell has argued, in posttrauma 'words are pseudosymbolic, plagiaristic imitations or metaphors $[\ldots]$ expressions of feeling rather than of meaning.' ${ }^{11}$ The post-traumatic writer, therefore, may be attracted to autobiographical fiction as a form of life-story telling that allows them to express feelings without being forced to attribute meaning to them and also engages the 'dilemma of representation' that mimics their psychic state. In order to understand how this alteration in language and meaning occurs in post-trauma, it will be useful to turn to the chemistry of 
memory to examine how sensory experiences, and the words and memories to which they give rise, are processed in non-traumatic encounters.

Memories are produced by a complex multiple system in which both sensory and semantic perceptions are processed in different areas of the brain and then stored. ${ }^{12}$ In the first instance, they are either stored as declarative 'episodic memories' - those specific events that we can remember clearly—or as 'general knowledge' or 'semantic content' only-for instance when we remember our times tables without remembering all the particular moments in which we memorized them. ${ }^{13}$ We cannot hold on to all of our episodic memories, however-there isn't enough space. So in sleep, our hippocampus floods with hormones that enable it to sort through them, deciding what to keep intact and what to distill into general knowledge. Thus, one of the things that happens when we dream is a sifting through of sensory perceptions removed from their semantic, general knowledge-based contexts. ${ }^{14}$ This is why in dreams we can see, for example, our mothers and our school chums and movie stars all side by side, or why our house may float and we may fly. All the normal contexts have been put aside and new rule-breaking combinations are possible. As clinical psychologist Robert Strickgold explains 'at its most complex, the integration of disparate memories leads to artistic and scientific creativity-the associating of objects and concepts in new, unexpected, but meaningful patterns. ${ }^{15}$ In normal memory functioning, that is, imagination is possible. Meaning itself is derived from this normal integration process of sensory perceptions into memory. But what happens to such memories in trauma and post-trauma? 
As Strickgold explains, PTSD is at its core, 'a consequence of failed memory processing, characterized in part by the [...] inappropriate dominance of specific episodic memories of traumatic events.' PTSD occurs, he says: when the brain fails to appropriately consolidate and integrate the episodic memory into the semantic memory system, and as a result, associations [...] fail to develop. The breakdown [...] leads to the continued maintenance of the episodic memory and its affect in an inappropriately strong and affect-laden form. ${ }^{16}$

Trauma, that is, has no perspective and no context in which it can be read, felt and understood. Unlike normally processed memories that are ascribed meanings and may give rise to meaningful creativity, traumatic events are premeaning and trapped as unprocessed sensory perception-stuck in one time and place that can reemerge whole and undiminished in sensory power at anytime and place.

Juliet Mitchell's argues that because of this difference in processing, PTSD has a specific effect on language. Mitchell writes:

the trauma sufferer withdraws from reality at the level of her or his own language. But then something reendows this language with energy [...] That which is spoken is the language of a mimed consensus or a compulsive repetition [...]; this maybe jargon and plagiarism[...]. Since there is not meaning to this language, the notorious lying of the hysteric fits in here. Such language is pseudosymbolic. ${ }^{17}$ What Mitchell describes here as the symptomatic pathology of trauma aligns with Friedlander's aesthetic of limitation and its 'dilemma' of representation and is 
equally useful for understanding the nature of post-traumatic autobiographical fiction. As a result of the traumatic event, Mitchell argues, the victim 'withdraws from reality at the level' of 'language.' This withdrawal might thus account for the recourse to fiction is taken by many post-trauma writers. But why must they write at all? As Mitchell suggests, trauma not only distances language from reality but also 'endows' that language 'with energy.' Post-trauma presents its victims, she argues, with a vital relationship to language, but a language that speaks in riddles and struggles to convey any meaning at all. Instead, the discourse of post-trauma becomes 'compulsive repetition' 'jargon' and 'plagiarism.' Like autobiographical fiction, that is, this conventional language of post-trauma apes familiar forms, yet is unable to attach clear meaning to themit is neither one thing nor the other.

This pseudosymbolic energetic language, I suggest, is precisely what we find in the ambiguous troping used compulsively in the works of many writers of autobiographical fiction. Virginia Woolf's repetitive use of waves, Julia Alvarez's gun stories; JG Ballard's empty swimming pools; Katherine Mansfield's windows; Jack Kerouac's angel/brothers; the fictions of each of these repeatedly reproduced images with contradictory and unstable meanings. ${ }^{18}$ Likewise, as DeLappe and Simpson argue, the purpose of contemporary counter-monuments is to ask questions about agency and representation ('Who is responsible for remembering and mourning, and how can artists respond?') rather than offer answers. 


\section{Lieux de memoire and Dangerous Speech}

The aim of such different memory projects as post-traumatic fictions and contemporary counter-monuments is therefore not truth-telling or remembrance in any simple reading of those categories. Both nevertheless attempt to evoke what Gilmore calls, in an echo of Foucault's four questions, 'the opportunity to reflect on how knowledge about truth is produced, by whom and in what forms. ${ }^{19}$ Works of this kind, visual, oral, and textual, function analogously as what Pierre Nora termed 'lieux dé memoire' or realms of memory that generate forms knowledge about the relations between truth, memory and memorial. As Nora explains, such '/ieux- places, sites,' represent the 'intent to remember.' Moreover, they 'have no referents in reality; or rather-they are their own referents-pure signs.[...] The lieux dé memoire is a templum: [...] a circle within which everything counts, everything is symbolic, everything is significant.' Even memoirs, Nora argues, can be understood in this way, if 'beyond simply exercising memory, they interrogate it. ${ }^{\prime 20}$ 'Lieux dé memoire' he states, 'arise out of a sense that there is no such thing as a spontaneous memory.' We need them because 'there are no longer any milieu dé memoire, settings in which memory is a real part of everyday existence. ${ }^{21}$ As Huyssen explains, this anti or counter-monumentalism is the result of a post 1945 reaction again 'monumental seduction' founded in mode of thinking that sees monumentality itself as 'unstable as any other aesthetic category. ${ }^{22}$

This instability can be traced in a number of other memory projects in a wide range of media: testimonies in courtrooms and on social networking sites, diaries, blogs, documentary films, trauma tweeting and the like attempt to 
capture and disseminate suffering in the hope of recognition, justice, and ultimately, commemoration. ${ }^{23}$ While each of these forms presents its own challenges to defining and circulating 'truth,' I argue here that they are analogous insofar as each may be read as a lieux dé memoire, and, moreover, a lieux that is articulated via the highly charged discourse of what Foucault termed 'parrhesia'- a mode of free speech 'linked to courage in the face of danger.' ${ }^{24}$ In such realms of memory not only can witness testimony and video footage question a state's version of events, but the imagination can become a vehicle to challenge the very jurisdiction of truth telling.

Historically, state or community-based artwork has been used to memorialize cultural traumas within certain limited parameters of meaning (heroism, for example). As DeLappe, Simpson and Huyssen among others note, recent years have seen a growing trend towards counter-monuments whose message is interrogative rather than didactic: Maya Lin's Vietnam War Veterans Memoria/ in Washington DC being perhaps the most famous of these. A parallel rise in works of autobiographically-based fictions that draw on traumatic experience indicates that this form has likewise become a popular vehicle of post-traumatic communication.

Autobiographical fictions that trouble the boundaries of truth, memory and representation, are perhaps the textual spaces that best reflect the longterm effects of trauma on such communication. As Holocaust historian Annette Wieviorka has written '[i]t is often supposed that history is better transmitted by works of non-fiction [nevertheless] at a time when death is omnipresent, the idea arises that the work of art is eternal, that it alone can guarantee memory, 
that is, immortality. ${ }^{25}$ Shoshana Felman echoes the necessity for imaginative renderings of trauma. 'We needed,' Felman writes, 'art - the language of infinityto mourn the losses and to face up to what in traumatic memory is not closed and cannot be closed. ${ }^{26}$ Nevertheless, both the process and the goal of posttraumatic art, whether literary, visual or otherwise, is dangerous territory precisely because of the impossibility of defining and therefore achieving the 'immortality' and 'infinity' such work seeks.

As Huyssen argues '[a]ll survivors of traumatic experiences face the difficult task of new beginnings. But the tension between traumatic symptom and new beginning will necessarily remain unresolved, generating ever new attempts at resolution. ${ }^{127}$ Post-traumatic autobiographical art whether narrative or otherwise is thus generative of knowledge and justice in the context of trauma, but is also, in Huyssen's view, a 'strategy of avoidance, and delusion of a new beginning' that represents an 'unattainable horizon of freedom.' ${ }^{28}$ As writers of post-trauma autobiographical fictions reach toward that horizon, moreover, they encounter the danger of speaking of their experience in the search for justice.

For Foucault, the 'parrhesiastic game' is a condition in which one's words cause one's life to be 'exposed' and in which, 'you risk death to tell the truth,' 'always in a situation where the speaker or confessor is in a position of inferiority with respect to the interlocutor. ${ }^{29}$ Might monuments and autobiographical fictions be analogous in this context as well? It is easy to see how one might risk death by raising a public memorial that challenges the narrative of a state-but what possible danger confronts the autobiographical fiction writer? As Felman reminds us 'a work of art cannot sentence to death. ${ }^{130}$ But death is not the only 
danger. And I would argue that just as stone monuments are replaced by virtual and endlessly revisable websites of suffering, autobiographical fictions of trauma, particularly serial autobiographical fictions (like those by Jamaica Kincaid, JM Coetzee, Jack Kerouac, Julia Alvarez and JG Ballard to name a few) can also be understood as repetitive lieux dé memoire conducted in parrhesiastic discourse whose blurring of genre and fragmented form is symptomatic of the insecurity of the terms in which it is spoken and heard. As Huyssen remarks, works that evoke a repetitive dialectic between 'memory and forgetting' can be read as evidence of 'multilayered traumatic experience.' ${ }^{31}$ Likewise the compulsively revisited and reimagined tropes that surface in serial autobiographical fictions suggests an unwillingness and/or inability to let go of the past.

Questions about what constitutes truth-telling in such sites are compounded by what Leigh Gilmore calls the writer's 'potentially disruptive performance in that location' that is 'freighted with risk'. ${ }^{32}$ By 'doing' trauma rather than 'being' trauma in such texts, 'they examine the relations among people that exist in the presence of trauma [...]in order to conceive of a self who can differ from the identity trauma imposes' ${ }^{33}$ Thus through the act of speaking out, victims become agents. Despite the 'extra-legal' forms that not only writers of autobiographical fiction but also sculptors, memoirists and architects choose to enact such agency, the public nature of their communication is subject to all kinds of pressures. As Gilmore argues if 'we insist against all reasonable qualification that the law is contaminated, testimony is partial and understanding is flawed', and yet 'all victims of trauma must nonetheless possess the innocence of one who has not yet lived in this messy world', then we will have 'brought 
standards to bear in this jurisdiction that work against an understanding of what justice looks like in the context of trauma. ${ }^{34}$ While as Felman has shown, 'a trial is presumed to be a search for truth [...] technically, it is a search for a decision [...] a force of resolution.' The purpose of the literary text is, on the other hand, she notes, to 'wrench apart what was covered over, closed up or covered up by the legal trial.' ${ }^{35}$ Huyssen similarly argues that, 'the power of the commemorative site is to keep the story alive, as opposed to entombing it in the realm of the unspoken. ${ }^{136}$ This longing to ask questions rather than reach decisions is a feature of post-traumatic autobiographical projects in many forms. These lieux dé memoire are thus analogous in their intention to trouble boundaries and critique the forms of truth and knowledge produced by more traditional means. The mode of challenge used by such sites is a rendering of traumatic experience in dangerous speech as they reach toward the unattainable horizon of freedom.

Here, I am reminded of Leigh Gilmore's term for understanding various forms of 'constitutive' 'self-representation: 'Alternative Jurisdictions,' in which 'a person's writing and a person's living contribute [...] to different legacies.' In The Limits of Autobiography, Gilmore is particularly interested in the 'coincidence of trauma and self-representation,' and what it reveals about 'autobiography, its history and especially its limits. ${ }^{37}$ Recall the representational experiences I mentioned earlier: although I did not write my friend's memoir or the witness statement, they are in some sense, autobiographical acts: I inspired the dramatic fictional character and signed off on the portrait of the wounded single mom and the stilted language of my witness statement. The self I performed in 
these different 'jurisdictions' collaborated in producing these alternative views of me. But although these acts trouble me, I do not feel endangered by them. Something more has to happen for that to occur: the agency invoked by representing traumatic experience through parahessiatic discourse.

\section{Sovereignty and Fiction}

Telling dangerous truths in works of autobiographical fiction offers what Gilmore calls 'an alternative jurisdiction for self-representation in which writers relocate the grounds of judgment, install there a knowing subject rather than a sovereign or representative self, and produce an alternative jurisprudence about trauma [and] identity. ${ }^{38}$ Gilmore's notion of an extra-legal, 'alternative jurisdiction,' moreover, might be mapped back onto Nora's lieux, as sites of symbolic significance in which memory is not simply 'exercised' but interrogated.

Central to Gilmore's formulation is the distinction she draws between 'the sovereign self $[\ldots]$ the one who can say 'this is who I am and how I came to be this way' and the 'knowing self' of her 'limit cases' which does not, 'ask who am I, but how can the relations in which I live [...] be reenacted through me.' Autobiographical fiction, she argues 'presents identity as it develops against the grain of sovereignty, the principles of law that underlie it, and the trauma they inflict and permit,' offering a 'critique of that position and the truth and knowledge produced by it. ${ }^{39}$ Here, Gilmore posits a 'knowing' 'critiquing self' against a 'sovereign' in an either/or relation, but if we conceive of autobiographical projects as processes, it may be more useful to understand these 'lieux dé memoire' as generative sites where the speaking self comes to know the instability of the category of sovereignty itself. Rather than a stable ' $\mathrm{I}$ ' 
that preexists the text, the 'I' of post-traumatic autobiographical fiction (like the state that commemorates its failure to protect citizens through monumental memorials) exposes the limits of supposedly invincible sovereignty.

In 1922, the political philosopher Carl Schmitt took on the Enlightenment view of the sovereign as the supreme lawmaker within his jurisdiction by arguing that the sovereign is 'he who decides on exception. ${ }^{140}$ Jacques Derrida developed Schmitt's idea by questioning whether sovereignty is therefore 'relieved of the condition of law? Or else does it exceed or betray it?' 'With respect to Schmitt,' Derrida suggests, 'sovereignty [...] [is] a certain power to give, to make, but also to suspend the law. ${ }^{41}$

In Derrida's reflections on 'Meridian' by Paul Celan, moreover, he examines the dynamic between Celan's repeated juxtaposition of the words 'majesty' and 'monarchy' as it 'displaces the sense' of 'sovereignty' itself, through a 'hyberbolic' 'bidding up' of power between more/most sovereign. This dynamic, for Derrida, points to a insoluble absurdity through which the 'sovereign' can be that which both creates and exceeds the law, enforces and transgresses jurisdictions and has meaning only insofar as that meaning is questioned by one which is or claims to be 'more sovereign. ${ }^{.42}$ As Derrida argues, one the one hand the 'fundamental axiomatic of responsibility or decision' is 'grounded in the sovereignty of the subject. ${ }^{.43}$ On the other hand, by thinking through the excesses and contradictions of 'sovereignty' one might conceive of a deconstructed (and potentially dangerous) figure of the sovereign: a differentiated, 'divided 'subject'[...] established progressively, laboriously, nevertheless imperfectly [...] not natural, forever and essentially unstable'. ${ }^{44}$ 
Gilmore's 'knowing subjects' are thus like Derrida's 'divided 'subject' who is 'established progressively' and 'imperfectly' in the 'not natural' site (lieux dé memoire) of the autobiographical act. As the lieux dé memoire of countermonuments and post-traumatic autobiographical fiction act-out experience by troubling the categories of truth, memory and sovereignty, we find a further link among these very different projects: the performativity of trauma.

\section{The Performance of Trauma}

In Max Saunders's study on modernist 'autobiografiction', he claims that '[w]riting is a kind of performance' and that in this cross-genre in particular, 'writers are consciously and deliberately shifting into the shapes of other subjectivities, and thus revealing the performance involved in the achievement of any subjectivity. ${ }^{45}$ Here, Saunders draws upon a long history of thought in which identity is read as a ritualized series of performances. Judith Butler's use of performativity theory in relation to gender is perhaps the most famous of these formulations, and in a Preface to her best selling Gender Trouble, she explains that this work built on Derrida's reading of Kafka's 'Before the Law. ${ }^{146}$ As Butler explains, in Kafka's parable 'the one who [...] sits before the door of the law, attributes a certain force to the law for which one waits. The anticipation of an authoritative disclosure of meaning is the means by which that authority is attributed and installed: the anticipation conjures the object.' It is this 'conjuring' from which Butler's reading of performativity developed as 'not a singular act but a repetition and ritual. ${ }^{47}$ While Butler's work uses this ritualized performativity to interrogate gender, others have reflected on relations between self-knowledge and performance in light of autobiography. 
In 1976, for example, Elizabeth Bruss argued that rather than an act of mimesis, autobiography was 'a personal performance, an action that exemplifies the character of the agent responsible for that action'. ${ }^{48}$ In 'Autobiography as De-Facement,' Paul de Man developed the idea of performance as generative, arguing that we 'assume the life produces the autobiography as an act produces its consequences, but [...] the autobiographical project may itself produce and determine the life.' ${ }^{49}$ Later, Sidonie Smith and Julie Watson asserted that 'there is no coherent "self" that predates stories about identity, about "who" one is.[...] We are always fragmented in time, taking a particular or provisional perspective [...] addressing multiple and disparate audiences. Perhaps, then, it is more helpful to approach autobiographical telling as a performative act.' ${ }^{50}$ In this 'performative view of life narratives' they argue, 'identities are not fixed or essentialized attributes,' instead, 'they are produced and reiterated through cultural norms, and thus remain provisional and unstable..$^{51}$

If the intention of such performances is to seek a form of compassion and justice, and if, as Emmanuel Levinas has argued '[j]ustice is a right to speak, ${ }^{152}$ the seeking, speaking and performative ' $\mathrm{I}$ ' is always revealing the artifice and instability at the heart of any exchange between speaker and interlocutor. These projects, therefore, will always be marked by instability and multiple aporia inherent in ideas of self hood, performance, and of course, traumatic speech itself.

\section{Genres of Truth}

Does autobiographical fiction tell the truth? That is often the question when autobiographical fiction is in the spotlight. While autobiography was once 
read as 'the master narrative of a sovereign self' ${ }^{53}$ this definition has collapsed in the face of contemporary challenges to the categories of sovereignty, memory and narration. Memoir, on the other hand, historically 'situated the subject in a social environment, as either observer or participant' and 'directs attention more toward the lives and actions of others than to the narrator.' ${ }^{54}$ But, like autobiography, memoir's defining terms have also been problematized as promoting, for example, 'an "I" that is explicitly constituted in the reports of the utterances and proceedings of others. ${ }^{155}$ Autobiographical truth, far from adhering to a stable set of codes and conventions, is instead 'an intersubjective exchange between narrator and reader, aimed at producing a shared understanding of the meaning of a life. ${ }^{156}$ As Paul Jay argues, 'if by 'fictional' we mean 'made up', 'created' or 'imagined'-something, that is, which is literary and not 'real' - then we have merely defined the ontological status of any text, autobiographical or not.' Drawing a distinction between autobiography and autobiographical fiction might be, Jay suggests, 'pointless'. ${ }^{57}$ Rather than asking if autobiographical fiction tells the truth, therefore, we might instead consider how far such works function as alternative modes of testimony and disclosure, and whether the knowledge and understanding they produce is therefore unique.

On those terms, the differences between memoirs, traditional imaginative fiction and autobiographical fiction can be seen in each form's distinctive relationship to questions not of truth but of the production new forms of knowledge. Memoirs, for example, convey remembered events, dialogue and reflections in the narrator's milieu. Memoirists ask themselves 'what was it like?' and use their memoirs to answer 'it was like this.' Traditional imaginative fiction, 
on the other hand, produces authority by requiring the writer to control the narration of events. The voice of the novel, therefore, is the voice of the author asking 'what if?' and answering in imaginative prose.

Autobiographical fiction, however, asks different questions and offers different responses, and as it does so has more in common with post-traumatic counter-monuments than it does with imaginative fiction and memoir. Autobiographical fictions concern the interplay between what the writer knows and remembers and what she or he doesn't and may never know. They are therefore produced in the interrogative space between one's felt life and a oncepotential life now lost to traumatic experience. This form is a narrative strategy for voicing the lacunae of the untold, unsaid, unremembered as well as for imagining what never was and never will be. In the case of autobiographical fiction that is based on traumatic experience, the interrogative space is also a dangerous space, and the untold likely buried for good reason. Like many postmodern monuments to suffering, autobiographical fiction asks 'why?' And because both question and response arise from an unstable self that challenges the possibility of sovereignty, the answer cannot be 'it was like this' or even 'what if it was like this?' but only ever 'perhaps it was like this.' 'Perhaps' is therefore the ambiguous voice of all such interrogative works of fiction and memorial art and architecture, and their value comes from this unique perspective. In the words of Andreas Huyssen, '[o]nce we acknowledge the constitutive gap between reality and its representation in language or image we must in principle be open to many different possibilities of representing the real and its memories [...] the semiotic gap cannot be closed by any orthodoxy of 
correct representation. ${ }^{58}$ It is this willingness to challenge representational and generic orthodoxies that produces vital new forms of understanding of human relations in the context of trauma.

In Cathy Caruth's work on trauma fiction, she states that in trauma 'what returns to haunt the victim is not only the reality of the violent event' but also the way that violence 'has not yet been fully known.' ${ }^{59}$ The place of post-traumatic autobiographical fiction, therefore, is to ask questions at the locked door within. As I noted earlier, however, Juliet Mitchell argues that this is no easy task, for 'the trauma sufferer withdraws from reality at the level of her or his own language,' creating a discourse without 'meaning,' an 'imitative or pseudosymbolic language. ${ }^{60}$ This language calls to mind Pierre Nora's templum - a space within which everything is significant, and also the genre blurring that occurs in many autobiographical projects. Max Saunders points to this blurring when he argues that the 'increasing awareness of fictionality inhering in the auto/biographic project can be accounted for by the machineries of displacement.[...] That is [...] a view of the self as constructed in the process of expression.' ${ }^{61}$ As Mitchell's patients withdraw into pseudosymbolic language and Saunder's 'autobiografictions' are symptoms of displacements of selfknowledge, both kinds of narratives are locked in an interrogative relation to the past whose mode of expression is the troubling of genre boundaries.

As Jessica Cantiello has argued, the serial self-representations in Julia Alvarez's autobiographic novels of traumatic experience are particularly interesting in this context as the central dilemma of her texts is storytelling itself. Alvarez's work, Cantiello contends, struggles 'with the opposition between the 
generative and the destructive aspects' of writing autobiographical fiction. ${ }^{62} \mathrm{Her}$ characters live in two worlds in which words are deadly weapons: the Dominican Republic under the brutal dictatorship of Rafael Trujillo and, after they immigrate, the USA, where Trujillo's informers continue to silence the truth. Alvarez's novels are thus burdened with a sense of betrayal in which storytelling is the cause of trauma, and yet she is compelled to continue to speak of the impact of this trauma in her serial fictional autobiography.

Other contemporary fictions test the limits of autobiography in different ways. Unlike the semi-confessional mode of Alvarez's work, the novels of NobelPrize willing author J.M. Cotzee have been read as anti-autobiographical. As Thomas Jones has argued, Coetzee's work plays 'with the question of why people should be at all interested in him as a human being. ${ }^{163}$ Coetzee's fictionalizing, that is, doesn't function in the conventional manner to offer ethical protection to the figures whose experience it narrates. Instead, his highly aestheticized narratives evade, blur, confound and ultimately critique the relation between writer, narrator, subject and reader, positioning a white Afrikaans man against the entire tradition of autobiographical confession. In doing so, Coetzee's novels present a strong counter-narrative to the growth of the market for memoir, by highlighting the form's potential for voyeurism, ghoulishness and snobbery. In an interview following the publication of the bestseller What is the What? (subtitled 'The Autobiography of Valentino Achak Deng, A Novel,' and based on events in the life of Deng as told to Eggers) author Dave Eggers sidesteps his blurring of genres in the work. Eggers states that for him the distinctions between fiction and literary non-fiction 'are sort of meaningless... 
they are fraternal twins. You can barely tell them apart. ${ }^{164}$ If the mode of telling is meaningless in Egger's view-what does matter to him? One answer can be found in the series he co-founded entitled Voice of the Witness, which uses oral histories to inform readers about struggles for human rights. For Eggers, perhaps, the relationship between speaker and listener may be more important than any verification of facts. Indeed, this sense of the communicative power of life stories can be found at the end of What is the What, as Valentino says 'Whatever I do, however I find a way to live, I will tell these stories [...] I speak to these people, and I speak to you because I cannot help it. It gives me strength, almost unbelievable strength to know that you are there [...] the collapsing space between us. [...]All the while I will know that you are there. How can I pretend that you do not exist? It would be almost as impossible as you pretending that I do not exist. ${ }^{65}$ And it is here that we witness the power and the limitations of fictive modes of autobiography. For the very presence of Eggers as writer/novelist that 'collapses' the space between Valentino and his listeners, enabling millions of readers to hear the tale of a 'lost boy,' also allows critics to challenge the 'truth' of this second-hand account, and close the door to the space Eggers hoped to open. ${ }^{66}$

Cathy Caruth argues that the fictive mode of autobiography that has its roots in traumatic experience attempts to tell us of a truth that is 'not otherwise available' and 'not yet been fully known.' ${ }^{67}$ In Totality and Infinity, however, Emmanuel Levinas asks whether truth can ever be separated from knowledge, arguing that ' $[\mathrm{t}]$ ruth is in effect, not separable from intelligibility; to know is not simply to record, but always to comprehend. We also say that to know is to 
justify, making intervene $[\ldots]$ the notion of justice. ${ }^{\prime 68}$ Thus Levinas links the knowledge of truth to the possibility of justice while Caruth reminds us that a condition of trauma is that the truth can never be fully known, and Mitchell argues that this is because traumatic experience affects memory at the level of language. I am brought back again here to Leigh Gilmore's idea of alternative jurisdictions and the limit cases that test them. Using the example of the debates on truth and historic representation that surrounded challenges to the 'truth' of the Nobel Prize winning testimonio 'I, Rigoberta Menchú, ${ }^{169}$ Gilmore notes the process by which 'the autobiographical politics of the resistant ' $\mathrm{I}$ ' and the 'we' called to witness' work together to produce 'an identity that exceeds its injury' and the 'experience to offer the materials for transformation.' ${ }^{70}$

In Gilmore's account, certain genre-blurring autobiographical fictions 'carve out a jurisdiction in which illegitimate subjects tell stories in forms marked out by elements of fiction'. In the 'limit cases' Gilmore examines, I would argue, traumatic experience and the desire for justice inscribe a complex relationship between the 'speech of witnesses', 'illegitimacy' and 'fiction.' And while these texts might not offer 'truth' read simply, they may be understood as producing the kind of 'comphrehension' called for by Levinas as a requisite of justice, as they inhabit what Gilmore calls 'the conditions in which alternative forms of knowledge about justice are compelled to appear. ${ }^{71}$ Like post-modern monuments to suffering, moreover, Gilmore's 'limit cases' may ask questions rather than answer them, but they also offer a unique form of knowledge production that is collaborative: such forms enable both speaker and listener to be in the same place at the same time, hearing the same stories. As Egger's 
Valentino tells us as he speaks in a narrative whose form is itself testing the limits of autobiography, 'I will know that you are there.' ${ }^{72}$

Contemporary public memorials present us with the names of those we have lost. Why they were lost is another matter, and the 'perhaps' of posttraumatic autobiographical fictions responds to, even if it does not answer, that question. For the post-trauma writer, storytelling itself is both the cause and symptom of suffering, offered in genre-blurring, pseudo-symbolic, and dangerous language. In this way such works function as textual versions of the unbuilt and virtual counter-monuments whose very form speaks to the complexity of representing the traumatic past.

\section{The Narcissistic ' I' of Traumatic Memory}

'Paradise absent is different from paradise lost.' Dominick LaCapra ${ }^{73}$

In 1836, Ralph Waldo Emerson argued that '[o]ur age is retrospective. It builds the sepulchres of the fathers.' ${ }^{74}$ From his age to our own, perspectives on the past and how best to represent it have changed. The memorials we now build are more likely to commemorate the suffering inflicted by our forefathers in the name of 'colonization' or 'progress' than the passing of patriarchal heroes. In much of the Western world, our age builds memorials to suffering, and the past is represented with regret rather than gratitude. Triumphal arches have made way for a genre of tribute sacred to the memory of victims of mass violence and political persecution. Like the virtual iraqimemorial.org, these countermonuments raise questions about the possibility of conveying stable meaning, symbolic or otherwise. In Berlin, the Holocaust is remembered by a field of concrete slabs; in London, clusters of stainless steel columns honour those lost 
on July $7^{\text {th }} 2005$, while the struggle of British suffragettes are represented by a huge, floating scroll outside New Scotland Yard; in Montana, ghostly bronze warriors on horseback recall the bravery of Native Americans at the Battle of Little Bighorn, rewriting the traditional narrative of Custer's last stand, and in lower Manhattan, huge square pits and reflecting pools set in the footprint of the World Trade Centre Towers mark the events of September $11^{\text {th }} 2001 .^{75}$

Perhaps the most well-known of this new age of commemorative tribute is the Vietnam Veterans War Memorial in Washington DC, dedicated in 1982. Art historian Levi Smith has argued that while the healing of the 'painful divisions' between the USA and Vietnam 'has taken place through many vehicles, including domestic and international politics [...] it is generally agreed that the Vietnam Veterans Memorial [...] has played a central role in helping Americans to come to terms with the past.' Smith goes on to ask how, 'despite the lack of any general agreement on the war's meaning, has the memorial managed to be so effective? ${ }^{\prime 76}$ One possible answer is that this effectiveness arises precisely from the memorial's resistance to articulating any fixed meaning. In Smith's view, the therapeutic success of the memorial comes 'first and foremost in its inclusive presentation of the names of the dead. This feature defines the memory of the war as that of the Americans that gave their lives in it. ${ }^{77}$ Like the memorials inscribed in post-traumatic autobiographical fiction, that is, its function is not only to question how we represent the past and mourn the dead, but also to call attention to the absence of what now can never be-the possibility of an untraumatised community that is lost forever. 
Dominick LaCapra has argued for the importance of drawing a distinction between 'absence' and 'loss' to our understanding of post-traumatic effects. As LaCapra notes, 'absence' as a category 'does not necessarily imply lack' because, 'one cannot lose what one never had.' By contrast, LaCapra suggests, 'loss is situated on an historical level and is the consequence of particular events.' When these categories are conflated, he argues, one misrecognises the true nature of one's trauma, because by 'converting absence into loss, one assumes that there was (or at least could be) some original unity, wholeness, security or identity which others have [...] made us lose.' To develop this argument, LaCapra notes that Freud 'saw melancholia as characteristic of an arrested process in which the depressed, self-berating and traumatized self, locked in compulsive repetition, is possessed by the past' and 'remains narcissistically identified with the lost object.' 'Mourning' for Freud in LaCapra's reading, however, 'brings the possibility of engaging trauma' and achieving 'cathexis' allowing 'one to begin again. ${ }^{78}$ LaCapra further argues that 'mourning might be seen as a form of working-through and melancholia as a form of acting-out. ${ }^{179}$

As I draw to the end of my own argument, I would like consider the relationships among these ideas of absence, loss, mourning, melancholia, 'working-through' and 'acting-out' as they function in and through post-traumatic memory projects. Do such projects, concrete or textual, operate as sites of mourning and cathexis, allowing those who produce and engage with them to 'begin again' as LaCapra suggests? Or are they more like melancholic narcissistic 'actings-out' which, through their very repetition, signal a conflation of loss and absence and arrested development? If, that is, a memorial to war veterans 
enacted a successful process of mourning, would not only one such memorial need be built? Likewise, if an autobiographical novel enabled its author to mourn a loss, would they need to write another one? Or another thirteen as in the case of Jack Kerouac? ${ }^{80}$ LaCapra's work suggests that what is being enacted in such projects is not (or, not only) a mourning of loss that is worked-through, but (or, but also) a melancholia of absence read as loss, acted out again and again. While LaCapra argues that 'absence' need not imply 'lack,' post-traumatic memory projects nevertheless often appear to read the absence of what now can never be (an untraumatised future) precisely as a loss. Moreover, in the case of autobiographical fictions of trauma, the construction of a narrating 'I' allows the writer to remain melancholically 'narcissistically identified with the lost object' by acting-out that loss in a narrative performance.

Levi Smith's work on the Vietnam Veteran's Memorial suggests that alongside the very real opportunity for mourning loss that this site offers, we may also see evidence of the melancholy narcissism that is characteristic of posttraumatic serial autobiographical fictions. As Smith notes, a striking but nevertheless ambiguous aspect of the design is the Wall itself, that 'points to the Washington Monument and the Lincoln Memorial, referring to both a 'good' war, the American Revolution, and to a tragic one, the Civil War. [...] Its most effective and influential ambiguous element, however is the high polish of its black granite surface that allows it to appear as a window or as a mirror. ${ }^{\prime}{ }^{1}$ This ambiguity was built in by designer Maya Lin from the start. As Smith points out, contestants bidding to design the monument were specifically asked to avoid 
making 'any political statement' or ascribing any meaning to the war in their plans. $^{82}$

Far removed from the triumphal message of the Air Force memorial or the narrative of bravery offered by the Iwo Jimo monument, both nearby, the Vietnam memorial's 'glittering surface symbolizes the essential indeterminateness and ambiguity of memory,' as Smith argues, and visitors are free to view that surface as 'a window leading to the past, or as a mirror bringing the past to the present.' This absence (and for some its critics, this lack) of clear narrative meaning has been the focus of attention, and thus the site has been subject to several design interventions, aimed at offering a clearer, more patriotic meaning to visitors. ${ }^{83}$ Such efforts miss the point of Maya Lin's design, which, as Charles Griswold has argued, is 'fundamentally interrogative.' ${ }^{84}$ This memorial, that is, demands of both designer and visitor the kind of ongoing interaction between art and life, representation, past and present, fact and memory that I argue is also central to post-traumatic autobiographical fiction: like those texts, Lin's memorial allows for a working-through of loss, but also a melancholic acting-out through its narcissistic mirroring of objectified suffering.

\section{The Discourse of Suffering}

Juliet Mitchell's reading of the pseudosymbolic language of trauma is useful for understanding these interrogative forms of memorials and autobiographical fiction. Such symbolically ambiguous templum install the posttraumatic culture or writer in the position to evoke what Mitchell calls the 'unsymbolizable absence'-what could not be seen from the immovable perspective inscribed by the traumatic event. By doing so, such projects, 
narrative or otherwise, allow victims to 'have access to the play of presence and absence. ${ }^{85}$ As the surface of the Memorial Wall provokes this kind of repositioning and serious play between window and mirror, loss and absence, self and other, so too do the ghostly warriors of the Little Bighorn Monument and the ambiguous stelae, marble scrolls and concrete columns of other memorials to the traumatic past.

As trauma evacuates meaning from experience, the chasm between subject and context, in Mitchell's view, begets a compulsion to create a story (however implausible or ambiguous) to fill the gap. 'That the story may be fiction and the words a lie is because the arbitrary relationship to their referents cannot be acknowledged,' she explains. Neither fully fact nor fiction, this is the hybrid nature of the post-traumatic narrative, in which: '[w]ords are pseudosymbolic, plagiaristic imitations or metaphors' that 'present rather than represent' and what is presented is a repositioned set of sensory experiences without context whose meaning is necessarily ambiguous. The reason for this as Mitchell argues is that 'traumatic language is a verbal version of the visual language of dreams: words are metaphors, similes, and symbolic equations [...] expressions of feeling rather than of meaning. ${ }^{86}$ This discourse of feeling and the quest for meaning has compelled post-traumatic writers to repeatedly visit the site of their inadequately processed experiences. In these realms of memory they offer painful sacrifice to the past in energetic, pseudosymbolic language that swerves between fact and fiction, unable, finally, to find a context in which their traumatic experiences will have meaning. 
The truth that autobiographical fiction tells is the truth of loss and of an unsymbolizable, narciscisstically installed absence than must be expressed but can only ever be insufficiently articulated by parrahesiatic post-traumatic speech. Like this essay, autobiographical fiction stumbles from the dark place of trauma, towards the intermittent light that falls between genres, disciplines, and memories, searching for a context in which its traumatic experiences might be fully understood. The place of such fiction thus exceeds the limits of literature and more nearly occupies the lieux dé memoire of post-modern cenotaphs: sacred, symbolic but finally empty spaces where we meet to speak and to hear the parrhesiatic language of ongoing suffering.

\footnotetext{
${ }^{1}$ Paul Celan, 'The Meridian,' Trans. Jerry Glen, in Jacques Derrida, Sovereignties in Question Ed. and Trans. Thomas Dutoit and O. Pasanen. (New York: Fordham UP, 2005), p. 173-85, p. 178.

2 Joseph DeLappe and David Simpson, 'Virtual Commemoration: The Iraqi Memorial Project' Critical Inquiry, 37: 4 (Summer 2011), pp.615-626.

3 Leigh Gilmore, The Limits of Autobiography (Ithaca: Cornell University Press, 2001), p. 12.

${ }^{4}$ Michel Foucault, Fearless Speech, ed. Joseph Pearson. (Los Angeles: Simotext(e), 2001), p. 170.

${ }^{5}$ Shoshana Felman, The Juridical Unconscious: Trials and Traumas in the Twentieth Century (Cambridge MA: Harvard UP, 2002) p. 3.

${ }^{6}$ Andreas Huyssen, Present Pasts: Urban Palimpsests and The Politics of Memory. (Stanford,CA: Stanford UP, 2003) p.94; p.29.

7 Robert Musil, 'Nachlaß zu Lebzeiten' Gesammette Werke, Vol 2, Ed. Adolf Frisé. (Reinbek: Rowohlt, 1978) pp. 506-9.

${ }^{8}$ Gilmore, Limits p. 147.

${ }^{9}$ On the genre's-blurring intertextual nature of autobiographical fiction see Max Saunders, SelfImpression: Life Writing, Autobiografiction and the Forms of Modern Literature. (Oxford: OUP, 2010) pp. 501-508. Suzette Henke first noted the fragmented forms of trauma fiction in Henke Shattered Subjects: Trauma and Testimony in Women's Life Writing. (Basingstoke: Macmillan, 1998).
}

${ }^{10}$ Saul Friedlander, Memory, History and the Extermination of the Jews in Europe (Bloomington:
University of Indiana Press, 1993), pp. 127-8. Theodor Adorno, for example, famously stated that
'Poetry after Auschwitz is barbaric.' Prisms $6^{\text {th }}$ Ed. Trans. Samuel and Shierry Weber. (Cambridge,
Mass: MIT Press, 1967), p. 34. Note, however, his troubling and expansion of this prohibition in his 
later work, in particular in the essay 'Elements of Anti-Semitism' in Adorno and Max Horkheimer Dialectic of Enlightenment (1944) Trans. John Cumming (London: Verso, 1997) pp. 168-208. Huyssen contextualizes of Adorno's statement as analogous to the biblical 'banning of graven images' 'Of Mice and Mimesis: Reading Spiegelman with Adorno' in Present Pasts, pp. 14-19.

11 Juliet Mitchell, 'Trauma, Recognition and the Place of Language,' 'Trauma, Recognition and the Place of Language' Diacritics, 28:4 (Winter 1998), pp. 121-33, p. 132.

${ }^{12}$ In this summary of the neuroscience of trauma and the biochemistry of memory I have drawn upon the work of Barbara Bottalico and Tommasso Bruni, 'Post-Traumatic Stress Disorder, Neuroscience and the Law' International Journal of Law and Psychiatry, 35 (2012), pp. 112-20, and Robert Strickgold 'EMDR: A Putative Neurobiological Mechanism of Action' Journal of Clinical Psychology, 58:1 (2002), pp. 61-75.

${ }^{13}$ Strickgold, p. 63.

${ }^{14}$ Strickgold p. 64.

${ }^{15}$ Strickgold, p. 66.

${ }^{16}$ Strickgold, p. 67.

17 Mitchell, p. 130.

${ }^{18}$ Elsewhere I have examined in detail the repetitive use of key tropes in the works of some posttraumatic writers. See Jensen, 'The Writer's Diary as Borderland.' Special Issue: Writing Between the Lives: Life Writing and the Work of Mediation. Life Writing, 9.3 (2012), pp. 315-325.

${ }^{19}$ Gilmore, Limits, p. 145.

${ }^{20}$ Pierre Nora, Realms of Memory: The Construction of the French Past, Vol I (New York: Columbia UP, 1996), pp. 14-19.

${ }^{21}$ Nora, Realms, pp. 1-7

${ }^{22}$ Huyssen (pp. 38-40) suggests that Nora developed this idea in relation to Foucault's criticism of the monumental as evoking an innate cultural longing 'the fascism in us all [...] that causes us to love power and to desire the very things that dominates and exploits,' Michel Foucault, Preface to Gilles Deleuze, Felix Guattari, Anti-Oedipus: Capitalism and Schizophrenia (Minneapolis: University of Minnesota Press, 1983), p.xxi.

23 'No doubt the world is being musealized [...] Total recall seems to be the goal,' Huyssen, p. 15.

${ }^{24}$ Michel Foucault, Fearless Speech Ed. Joseph Pearson. (Los Angeles: Simotext(e), 2001), p. 170.

${ }^{25}$ Annette Wieviorka, The Era of the Witness Trans. Jared Stark. (Ithaca: Cornell UP, 2006), p. 22.

${ }^{26}$ Felman, Juridical, p. 107.

${ }^{27}$ Huyssen, p. 151.

${ }^{28}$ Huyssen, pp. 152-3.

${ }^{29}$ Foucault, Fearless, p. 170.

${ }^{30}$ Felman, Juridical, p. 152. 
${ }^{31}$ Huyssen, p. 146.

32 Leigh Gilmore, 'Jurisdictions: I, Rigoberta Menchú, The Kiss and Scandalous Self-Representation in the Age of Memoir and Trauma'. Signs, 28:2 (Winter 2003), pp. 695-718, p. 699.

${ }^{33}$ Gilmore, Limits, p. 146.

${ }^{34}$ Gilmore Jurisdictions, p. 698.

${ }^{35}$ Felman, Juridical, p. 54; p. 95.

${ }^{36}$ Huyssen, p. 101.

${ }^{37}$ Gilmore, Limits, p. 36

${ }^{38}$ Gilmore, Limits, p. 143. Kincaid's series of autobiographical novels includes At the Bottom of the River (1983), Annie John (1985), Lucy (1991), Autobiography of my Mother (1995); My Brother (1997). She clarified her sense of the juridical place of her own work: 'Everything I say is true, and everything I say is not true. You couldn't admit any of it to a court of law.' Kay Bonetti, 'An Interview with Jamaica Kincaid' The Missouri Review, 25.2 (Summer 2002). Accessed online March 162012 http://www.missourireview.org/content/dynamic/view text.php?text id=1947

${ }^{39}$ Gilmore, Limits, pp. 146-9.

${ }^{40}$ Carl Schmitt, Political Theology: Four Chapters on the Subject of Sovereignty Trans. George Schwab, (1922). (Cambridge: Cambridge UP, 1985), p. 5.

41 Jacques Derrida, The Beast \& The Sovereign, Vol I, Ed. Michel Lisse, M. Mallet, and G. Michand, Trans. Geoffrey Bennington. (Chicago: University of Chicago Press, 2009) p. 16.

42 Jacques Derrida, 'Majesties,' Sovereignties in Question, p. 117.

43 Jacques Derrida, Without Alibi Ed. and Trans. Peggy Kamuf. (Stanford: Stanford UP, 2002), p. xxix.

44 Jacques Derrida and Elisabeth Roudinesco, For What Tomorrow... A Dialogue Trans. Jeff Fort. (Stanford: Stanford University Press, 2004), p. 236. On the danger of deconstructing sovereignty, Derrida wrote 'One cannot [...] threaten the whole principle of sovereignty without compromising [...] what are today the most stable foundations of morality, law and politics,' Without Alibi, p. xix.

45 Max Saunders, Self-Impression, p. 515; p. 526.

46 Judith Butler, 'Preface' (1999), Gender Trouble. (New York: Routledge, 1999) pp. vii--xxvi, p. xiv. Frank Kafka, 'Before the Law,' Franz Kafka: The Complete Stories and Parables 3-4, Ed Nahum N. Glatzer Trans. Willa \& Edwin Muir (New York: Quality Paperback Book Club, 1971); Derrida, Acts of Literature, Ed. Derrida and Derek Attridge. (New York: Routledge, 1992) pp. 187-220.

${ }^{47}$ Butler, 'Preface' (1999), p. xiv.

${ }^{48}$ Elizabeth Bruss, 'Eye for I,' Autobiographical Acts: The Changing situation of a Literary Genre. (Baltimore: Johns Hopkins UP, 1976), p. 300.

${ }^{49}$ Paul De Man, 'Autobiography as De-Facement,' Modern Language Notes, $94: 5$ (1979), pp. 91930. 
50 Sidonie Smith and Julia Watson, 'Appendix A: "Sixty Genres of Life Narrative,"' Reading Autobiography: A Guide for Interpreting Life Narratives. (Minneapolis: University of Minnesota Press, 2010), pp. 253-86.

${ }^{51}$ Smith and Waston, Reading, p. 143. As Butler and Smith and Watson all note, this version of the self in all its subsequent forms, derives from Nietzche's insight that 'there is no "being" behind doing, acting, becoming.' Nietzche, On the Geneaology of Morality. (Cambridge: CUP, 2006), p. 13. See also Sidonie Smith, 'Performativity, Autobiographical Practice, Resistance,' A/B Autobiographical Studies, 10: 1 (Spring 1995) pp. 17-33.

52 Emmanuel Levinas, Totality and Infinity Trans. Alphonso Lingis. (Pittsburgh PA, Duquesne UP, 1969), p. 297.

${ }^{53}$ Smith and Watson, Reading, p. 3.

${ }^{54}$ Smith and Watson, Reading, p. 274.

${ }^{55}$ Lee Quinby, 'The Subject of Memoirs,' Decolonizing the Subject. (Minneapolis: University of Minnesota UP), pp. 297-320, p. 299.

${ }^{56}$ Smith and Watson, Reading, p. 13.

57 Paul Jay, Being in the Text: Autobiography and the Problem of the Subject. (Baltimore: Johns Hopkins UP, 1996) p. 16.

${ }^{58}$ Huyssen, p. 19.

${ }^{59}$ Cathy Caruth, Unclaimed Experience: Trauma, Narrative and History. (Baltimore: Johns Hopkins UP, 1996), p. 6.

60 Juliet Mitchell, 'Trauma,' pp. 129-130.

${ }^{61}$ Saunders, p. 502.

62 See Jessica Wells Cantiello, 'That Story about the Gun: Pseudo-Memory in Julia Alvarez's Autobiographical Novels' Melus: Multi-Ethnic Literature of the U.S., 36:1 (Spring 2011), pp. 83-108, p. 85 .

63 See Thomas Jones, 'J.M.Coetzee:Summertime' Guardian, September 6 2009. Accessed online March 16 2012. http://www.guardian.co.uk/books/2009/sep/06/jm-coetzee-summertime

${ }^{64}$ See Tim Adams. 'What is the What? by Dave Eggers' Guardian, May 20 2007. Accessed online March 16 2012. http://www.guardian.co.uk/books/2007/may/20/fiction.features.

${ }^{65}$ Dave Eggers, What is the What? The Autobiography of Valentino Achak Deng: A Novel (London: Hamish Hamilton, 2007), p. 535.

${ }^{66}$ Eggers responds to these critics further in this interview. See Adams http://www.guardian.co.uk/books/2007/may/20/fiction.features

${ }^{67}$ Caruth, p. 6.

${ }^{68}$ Levinas, p. 502.

${ }^{69}$ As Gilmore explains, in 1998, 'Nobel Peace Prize Recipient Rigoberta Menchú was accused of propagandistic distortion and outright lying' in her celebrated testimonio. At stake, Gilmore argues, were the limits of truth and the representation of traumatic experience. Gilmore, Jurisdictions, $\mathrm{p}$. 
695. See also David Stoll, Rigoberta Menchú and the Story of All Poor Guatemalans (Boulder Co: Westview Press), 1998.

${ }^{70}$ Gilmore, Jurisdictions, p. 707.

${ }^{71}$ Gilmore, Limits, p. 147.

${ }^{72}$ Eggers, What is the What?, p. 535.

${ }^{73}$ Dominick La Capra, 'Trauma, Absence, Loss,' Critical Inquiry, 25:4, (Summer 1999), pp. 696727, p. 707.

${ }^{74}$ Ralph Waldo Emerson. Nature (Boston: James Munroe and Co: 1836). Digitised first edition. http://www.archive.org/details/naturemunroe00emerrich.

${ }^{75}$ Memorial to the Murdered Jews of Europe in Berlin, by Peter Eisenman. It consists of a 4.7 acres site covered with 2,711 concrete slabs or 'stelae', arranged in a grid pattern on a sloping field. http://www.pbs.org/wgbh/pages/frontline/shows/germans/memorial/eisenman.html

The Suffragette Memorial, London Erected in 1970. http://parliamentandwomen.wordpress.com/2011/04/11/suffragette-fellowship-memorial/

The 07/07 Memorial, Hyde Park, London. Designed by Carmody Groarke with Anthony Gormley. 52 stainless steel stelae commemorate the 52 victims, arranged to symbolise the four attacks. 'The $3.5 \mathrm{~m}$ tall stainless steel pillars symbolised the random nature of the loss of life.' http://news.bbc.co.uk/1/hi/8137265.stm

Little Bighorn Battlefield National Monument reinterprets the site of the Battle of the Little Bighorn, 1876. In 1940, this site was purchased to honour Custer and his defeated Cavalry, but in the 1990s, the park was redesignated at the behest of representatives of Native American interests. http://www.nps.gov/libi/index.htm

The National September 11 Memorial \& Museum, Lower Manhattan, New York by Israeli-American Michael Arad. The title of the winning design is 'Reflecting Absence.' http://www.911memorial.org/

${ }^{76}$ Levi Smith, 'Window or Mirror: The Vietnam Veterans Memorial and the Ambiguity of Remembrance' Peter Homans, ed, Symbolic Loss: The Ambiguity of Mourning and Memory at Century's End(Charlottesville and London: University Press of Virginia, 2000), pp. 105-125, p. 105.

${ }^{77}$ Levi Smith, 'Window or Mirror,' p. 106.

${ }^{78}$ LaCapra, 'Trauma, Absence, Loss,' pp. 701-13.

${ }^{79}$ Sigmund Freud, 'Remembering, Repeating and Working-Through (further Recommendations on the Technique of Psychoanalysis II)'(1914), The Standard Edition of the Complete Psychological Works of Sigmund Freud, 12: 145-56; 'Mourning and Melancholia' (1917) 14: 237-60. See also LaCapra, Representing the Holocaust. (Ithaca: Cornell UP, 1996).

${ }^{80}$ I am currently working on a companion essay that examines a number of serial autobiography written post-trauma in detail. Jack Kerouac saw his fourteen novel fictional autobiography (the Duluoz Legend), as a response to the death of his brother ('the whole reason why I ever wrote at all [was] because of Gerard,' Kerouac, Visions of Gerard (New York: Farrar, Strauss, 1963) p. 10.

${ }^{81}$ Levi Smith, p. 106. 
82 Levi Smith cites the Question and Answer Sheet 10 February 1981, Records of the Vietnam Veterans Memorial Fund, container n. 63, Manuscript Division, Library of Congress. 'The specifications sent to prospective designers cautioned them against making "any political statement" in their designs.' Smith, p. 107.

${ }^{83}$ Levi Smith, p. 116. Smith notes that a 'compromise was reached over the course of a year in which an inscription was added to the memorial and a flag and a sculpture of three infantrymen were placed near it,' p. 107.

${ }^{84}$ Charles Griswold. 'The Vietnam War Memorial and the Washington Mall: Philosophical Thoughts on Political Iconography' Critical Inquiry, 12 (Summer 1986), pp. 699-719, p. 711.

${ }^{85}$ Mitchell, pp. 129-130.

${ }^{86}$ Mitchell, p. 132. 